\section{CarakaTanil \\ Journal of Sustainable Agriculture \\ ISSN 2613-9456 (Print) 2599-2570 (Online)}

\title{
Carbon Organic Content under Organic and Conventional Paddy Field and its Effect on Biological Activities (A Case Study in Pati Regency, Indonesia)
}

\author{
Supriyadi*, Melja Karni Pratiwi, Slamet Minardi and Nanda Lintang Prastiyaningsih
}

Department of Soil Science, Faculty of Agriculture, Universitas Sebelas Maret, Surakarta, Indonesia

*Corresponding author: supriyadi_uns@staff.uns.ac.id

\begin{abstract}
The low organic matter content of paddy soils impacts the declining quality of land. Without the efforts to enrich the soil organic matter (SOM) content, the productivity of paddy fields will decrease or the need for inorganic fertilizers will increase to reach the level of yield. The present research aims to determine the effect of differences in organic and conventional paddy fields management practices on soil organic carbon (SOC) content and biological activities. The research was conducted from July to September 2018 on organic and conventional paddy fields in Dukuhseti Sub-district, Pati Regency, Central Java, Indonesia. Sampling points were taken from six organic samples in the organic paddy fields while the other six samples were taken from conventional paddy fields. The variables observed in this research were organic $\mathrm{C}, \mathrm{pH}$, total $\mathrm{N}$ soil, total bacterial colonies, soil respiration and microbial biomass $\mathrm{C}$. The results show that the organic $\mathrm{C}$ content in the organic paddy field (2.4\%) was higher than that of the conventional paddy field (1.8\%). The $\mathrm{C}$ content of organic paddy fields increased by $0.6 \%$. The differences of the total bacterial colonies, soil respiration and microbial biomass $\mathrm{C}$ between organic paddy fields and conventional paddy fields were $11.5 \mathrm{CFU} \mathrm{g}{ }^{-1}, 7.42 \mathrm{mg} \mathrm{CO}_{2}$ week $^{-1}$ and 0.51 $\mu \mathrm{g} \mathrm{g}^{-1}$, respectively, because the use of organic farming systems could improve the biological nature of soils and caused biological activity in organic paddy fields to have the highest value compared to conventional paddy fields.
\end{abstract}

Keywords: biological activities; conventional; organic; paddy fields; soil organic carbon

Cite this as: Supriyadi, Pratiwi, M. K., Minardi, S., \& Prastiyaningsih, N. L. (2020). Carbon Organic Content under Organic and Conventional Paddy Field and its Effect on Biological Activities (A Case Study in Pati Regency, Indonesia). Caraka Tani: Journal of Sustainable Agriculture, 35(1), 108-116. doi: http://dx.doi.org/ 10.20961/carakatani.v35i1.34630

\section{INTRODUCTION}

Rice is a staple food for more than $50 \%$ of the world's population (Nachimuthu et al., 2015). An increase in rice production is needed to meet the demand for food from a rapidly developing population (Liu et al., 2016). Improving soil fertility, especially soil organic carbon (SOC) content (Pospíšilová et al., 2011), has an important role in maintaining a sustainable growth in rice yield (Zhao et al., 2016). Increasing SOC content mainly through organic amendments (such as green manure, manure and crop residues) can improve soil fertility and crop yields (Zhang et al., 2016).

Rice cultivation is a dominant factor causing the low productivity of rice plants, one of which is the problem of soil fertility, especially the content of organic matter in the soil. Maintaining SOC on agricultural land is important for increasing agricultural productivity. Tillage can often destroy soil organic matter (SOM) and accelerate the movement of SOM into deep soil. Various agricultural practices such as residual retention, tillage, fertilization and irrigation affect

\footnotetext{
* Received for publication September 19, 2019 Accepted after corrections January 17, 2020
} 
agricultural land, including soil fertility and regional and/or global carbon (C) cycles. Changes in soil chemistry under reduced environmental conditions and a very limited supply of $\mathrm{O}_{2}$ in the inundation system greatly put effect on the dynamics of SOC. Major processes that contribute to the dynamics of SOC in a soil-waterlogged soil environment include the changes in soil $\mathrm{pH}$ and the reduction of $\mathrm{C}$ and $\mathrm{N}$ (Fageria et al., 2011).

Paddy fields are sources of high capacity soil C sequestration (Lu et al., 2009). Various land management practices, such as tillage, straw management, fertilization, irrigation and crop rotation, significantly influence GHG emissions (Arunrat et al., 2017), soil C sequestration (Bhattacharyya et al., 2010), rice production and food security (Nguyen, 2006). Most of Indonesia's agricultural land has low organic matter content, while $23 \%$ is moderate and $4 \%$ is high. Without the efforts to enrich SOM content, it is feared that the productivity of paddy fields will decrease or the need for inorganic fertilizers will increase to reach the level of yield achieved today in a short time, but if the waste is returned to the soil, gradually there will be an increase in SOM content.

One of the important strategies to overcome a decrease in rice production in conventional farming systems is by increasing SOC storage. SOC has a strong relationship with crop yields (Lal, 2004). Rice production increases $10-50 \mathrm{~kg}$ $\mathrm{ha}^{-1}$ with each additional $\mathrm{C}$ stock of 1 ton $\mathrm{C} \mathrm{ha}{ }^{-1}$ year $^{-1}$ (Lal, 2011). A combination of land preparation and straw returns has a significant effect on SOC fraction, the results vary under different soil or climate conditions. Treatment without tillage and with shallow tillage with residual cover have significantly higher SOC than conventional tillage without residue cover. Ghimire et al. (2017) have revealed that in the Chitwan Valley of Nepal, without tillage with the application of plant residues in the upper soil depths, the SOC sequestration was much higher than conventional tillage with crop residues.

The area of Pati Regency is 150,368 ha, consisting of 58,448 ha (39.38\%) of paddy fields and 91,920 ha $(60.62 \%)$ of non-paddy fields. Based on the description above, this research is important for paddy fields. Previous research on organic $\mathrm{C}$ in paddy soils with organic and conventional farming systems in Juwiring and Bantul have been carried out, but in this research, additional biological activities and differences in research locations are given more attention. The research location has implemented organic farming for three years, but studies on $\mathrm{C}$ content and biological activity have not been conducted. This research aims to determine the influence of differences in management practices between organic and conventional paddy fields on SOC content and soil biological activities, and to find out the relationship between organic $\mathrm{C}$ content in the soil and biological activities in the research location.

\section{MATERIALS AND METHOD}

Sampling and field observations were carried out in organic and conventional paddy fields in Dukuhseti Sub-district, Pati Regency, Central Java, Indonesia. The research was conducted from July to September 2018. This study is descriptive exploratory through field surveys. Sampling locations were determined by stratified random sampling using Land Map Units. Soil sampling for laboratory analysis was done using purposive sampling. Sampling points were taken from six organic samples in the organic paddy field while six samples were taken from conventional paddy fields.

Organic agriculture is a crop production approach with maximum reliance on locally or farm-produced fertilizers or manures and minimum reliance on chemical and synthetic fertilizers. On the other hand, conventional agriculture is another approach with heavy reliance on synthetic agro-chemicals. Sampling at each point was carried out at $0-20 \mathrm{~cm}$ depth with $1 \mathrm{~m}$ distance each in the direction, taking at five point. The samples were then combined, placed in plastic bags that had been labeled. All soil samples for biology were put in a special place (cool box) before being analyzed in the laboratory. The analysis of samples was conducted in the laboratory and was repeated three times, the total treatments were 36 .

The tools used for field analysis include maps, GPS (Global Positioning System), ground drill, label paper, cool box, clinometer, hoe, plastic and stationery while the materials used include $\mathrm{pH}$ stick, aquades, $\mathrm{KCl}, \mathrm{H}_{2} \mathrm{O}_{2}, \mathrm{~K}_{7} \mathrm{Fe}_{2} \mathrm{SO}_{4}, \mathrm{KCNS}, \mathrm{HCl}$ $1.2 \mathrm{~N}$ and $\mathrm{HCl} 2 \mathrm{~N}$. The equipment used in the laboratory analysis includes $\mathrm{pH}$ meters, spectrophotometers, pipettes, electric heaters, digestion tubes, Petri dish, micropipettes, desiccators, electric pumps, Whatman filter paper 
and weigh bottles while the materials used include aquades, $\mathrm{Zn}$ grains and chemicals such as $\mathrm{KCl}$, alcohol, $\mathrm{NaCl}, \mathrm{NaOH}, \mathrm{H}_{3} \mathrm{BO}_{3}$, concentrated $\mathrm{H}_{2} \mathrm{SO}_{4}$, standard solutions, organic paddy soils and conventional, NA media, sterile physiological salts, $\mathrm{KOH} 0.2 \mathrm{~N}$, phenolphthalein, $\mathrm{HCl} 0.2 \mathrm{~N}$, methyl orange, $\mathrm{BaCl}_{2} 3 \mathrm{~N}, \mathrm{~K}_{2} \mathrm{Cr}_{2} \mathrm{O}_{7} 1 \mathrm{~N}$ solution, $0.5 \mathrm{M} \mathrm{K}_{2} \mathrm{SO}_{4}$, chloroform and lime soda.

The observation variables in this study consisted of chemical and biological properties of soil, including organic $\mathrm{C}$ (Walkley and Black method), soil $\mathrm{pH}$ (soil: $\mathrm{H}_{2} \mathrm{O}$ Electrometric method), total soil $\mathrm{N}$ (Kjeldahl method), total bacterial colonies (total plate count), soil respiration (Verstraete method by Anas, 1989) and microbial biomass $\mathrm{C}$ (Fumigation and Extraction method). The results of the study for each organic and conventional paddy fields were analyzed using a T-test with a level of $95 \%$ and a correlation test using SPSS version 23 for windows.

\section{RESULTS AND DISCUSSION}

\section{General condition of research location}

The climate type in Dukuhseti Sub-district according to Oldemen is E1 (if there are less than three consecutive wet months and less than two dry months). This research location has two management systems, organic and conventional systems with technical irrigation. Fertilization in organic paddy fields was done before planting with organic fertilizer of cow manure as much as $4,000-5,000 \mathrm{~kg} \mathrm{ha}^{-1}$. Fertilization in conventional paddy fields was conducted using urea fertilizer as much as $300 \mathrm{~kg} \mathrm{ha}^{-1}$, superphosphate SP-36 as much as $50 \mathrm{~kg} \mathrm{ha}^{-1}$ and $\mathrm{KCl}$ fertilizer as much as $75 \mathrm{~kg} \mathrm{ha}^{-1}$. The conversion of paddy fields from conventional to organic was for three years. Data on soil sampling characteristics are presented in Table 1 .

Table 1. The characteristic of sampling locations

\begin{tabular}{cccccl}
\hline $\begin{array}{c}\text { Altitude } \\
(\mathrm{m} \text { asl })\end{array}$ & $\begin{array}{c}\text { Type of } \\
\text { soil }\end{array}$ & $\begin{array}{c}\text { Paddy field } \\
\text { management systems }\end{array}$ & Latitude & Longitude & \multicolumn{1}{c}{ Species } \\
\hline 22 & Alluvial & Organic & $6^{\circ} 27.904^{\prime} \mathrm{S}$ & $110^{\circ} 58.746^{\prime} \mathrm{E}$ & Rice, grass, azolla \\
21 & Alluvial & Organic & $6^{\circ} 29.251^{\prime} \mathrm{S}$ & $110^{\circ} 58.936^{\prime} \mathrm{E}$ & Rice, grass, azolla \\
26 & Alluvial & Organic & $6^{\circ} 29.6900^{\prime} \mathrm{S}$ & $110^{\circ} 58.687^{\prime} \mathrm{E}$ & Rice, grass, azolla \\
26 & Alluvial & Organic & $6^{\circ} 25.973$ 'S & $110^{\circ} 59.477^{\prime} \mathrm{E}$ & Rice, grass, azolla \\
5 & Alluvial & Organic & $6^{\circ} 26.895$ 'S & $111^{\circ} 2.068^{\prime} \mathrm{E}$ & Rice, grass, azolla \\
23 & Alluvial & Organic & $6^{\circ} 27.363$ 'S & $111^{\circ} 2.404^{\prime} \mathrm{E}$ & Rice, grass, azolla \\
30 & Alluvial & Conventional & $6^{\circ} 27.758^{\prime} \mathrm{S}$ & $111^{\circ} 2.229^{\prime} \mathrm{E}$ & Rice \\
30 & Alluvial & Conventional & $6^{\circ} 28.109$ 'S & $111^{\circ} 1.921^{\prime} \mathrm{E}$ & Rice \\
25 & Alluvial & Conventional & $6^{\circ} 28.841^{\prime} \mathrm{S}$ & $111^{\circ} 1.804^{\prime} \mathrm{E}$ & Rice \\
24 & Alluvial & Conventional & $6^{\circ} 29.470^{\prime} \mathrm{S}$ & $111^{\circ} 2.785^{\prime} \mathrm{E}$ & Rice \\
40 & Alluvial & Conventional & $6^{\circ} 25.577 \mathrm{~S}$ & $110^{\circ} 59.916^{\prime} \mathrm{E}$ & Rice \\
40 & Alluvial & Conventional & $6^{\circ} 27.641^{\prime} \mathrm{S}$ & $111^{\circ} 1.497^{\prime} \mathrm{E}$ & Rice \\
\hline
\end{tabular}

Note: $\mathrm{m}$ asl $=$ meter above sea level

The soil type in this research site belongs to alluvial soil. The results of mineral and chemical analyses of alluvial wetland soils published by Prasetyo (2008) reported that the paddy soils of alluvial deposits have highly varied mineral composition and chemical properties, influenced by the type of sediment material, which was the parent material. Vegetation in the fields applying organic rice farming system included rice, grass and Azolla, while the vegetation in conventional paddy fields merely comprised rice plantation. This shows that the diversity of vegetation in organic paddy fields was better than that in conventional paddy fields.

\section{Organic $\mathrm{C}$ content, $\mathrm{pH}$ and total $\mathrm{N}$ in organic and conventional paddy fields}

The results of the analysis of $\mathrm{C}$ content, soil $\mathrm{pH}$ and total $\mathrm{N}$ in organic and conventional paddy fields are presented in Table 2. Based on the rating provided by the Soil Research Institute (2009), the results of the analysis of organic $\mathrm{C}$ content shown in Table 2 were moderate to low. The highest levels of organic $\mathrm{C}$ were found at the point sample of organic 1 , which was $2.6 \%$, while the lowest $\mathrm{C}$ level was found in the sample point of conventional 2 , which was $1.5 \%$. The results of the statistical analysis (T-test) are presented in Table 3. The analysis shows that there was a 
highly significant difference between the $\mathrm{C}$ content in the organic paddy fields and that in the conventional paddy fields. The average organic $\mathrm{C}$ content in organic paddy fields was $2.4 \%$, while the average organic $\mathrm{C}$ content in conventional paddy fields was $1.8 \%$ with a significant value $\mathrm{p}<0.01$. SOC is an essential component of the global C cycle (Viscarra Rossel et al., 2019). Organic content affects the amount and the metabolic activity of soil organisms.

Table 2. The results of the analysis of organic $\mathrm{C}$ content, $\mathrm{pH}$ and total $\mathrm{N}$ at each sample point

\begin{tabular}{lccc}
\hline \multicolumn{1}{c}{ Sample point } & Organic C $(\%)$ & \multicolumn{1}{c}{ Soil pH } & Total N $(\%)$ \\
\hline Organic 1 & $2.6( \pm 0.1) \mathrm{M}$ & $6.7( \pm 0.1) \mathrm{N}$ & $0.45( \pm 0.03) \mathrm{M}$ \\
Organic 2 & $2.5( \pm 0.3) \mathrm{M}$ & $6.9( \pm 0.1) \mathrm{N}$ & $0.42( \pm 0.05) \mathrm{M}$ \\
Organic 3 & $2.1( \pm 0.4) \mathrm{M}$ & $6.7( \pm 0.0) \mathrm{N}$ & $0.43( \pm 0.11) \mathrm{M}$ \\
Organic 4 & $2.5( \pm 0.1) \mathrm{M}$ & $6.7( \pm 0.1) \mathrm{N}$ & $0.33( \pm 0.02) \mathrm{M}$ \\
Organic 5 & $2.5( \pm 0.2) \mathrm{M}$ & $7.3( \pm 0.1) \mathrm{N}$ & $0.42( \pm 0.06) \mathrm{M}$ \\
Organic 6 & $2.3( \pm 0.1) \mathrm{M}$ & $7.1( \pm 0.1) \mathrm{N}$ & $0.42( \pm 0.06) \mathrm{M}$ \\
Conventional 1 & $1.8( \pm 0.5) \mathrm{L}$ & $5.1( \pm 0.1) \mathrm{A}$ & $0.30( \pm 0.11) \mathrm{M}$ \\
Conventional 2 & $1.5( \pm 0.0) \mathrm{L}$ & $6.1( \pm 0.1) \mathrm{A}$ & $0.31( \pm 0.06) \mathrm{M}$ \\
Conventional 3 & $1.8( \pm 0.2) \mathrm{L}$ & $6.3( \pm 0.1) \mathrm{SA}$ & $0.28( \pm 0.02) \mathrm{M}$ \\
Conventional 4 & $1.9( \pm 0.2) \mathrm{L}$ & $6.4( \pm 0.1) \mathrm{SA}$ & $0.27( \pm 0.04) \mathrm{M}$ \\
Conventional 5 & $1.8( \pm 0.1) \mathrm{L}$ & $5.0( \pm 0.0) \mathrm{A}$ & $0.31( \pm 0.09) \mathrm{M}$ \\
Conventional 6 & $1.9( \pm 0.1) \mathrm{L}$ & $6.1( \pm 0.1) \mathrm{SA}$ & $0.25( \pm 0.01) \mathrm{M}$ \\
\hline
\end{tabular}

Note: $\mathrm{M}=$ Moderate; $\mathrm{L}=$ Low; $\mathrm{N}=$ Neutral; $\mathrm{A}=$ Acid; $\mathrm{SA}=$ Slightly Acid

Table 3. The results of analysis of T-test for organic $\mathrm{C}$ content, soil $\mathrm{pH}$ and total $\mathrm{N}$

\begin{tabular}{lccc}
\hline $\begin{array}{c}\text { Paddy field } \\
\text { management system }\end{array}$ & $\begin{array}{c}\text { Organic } \\
\mathrm{C}(\%)\end{array}$ & $\begin{array}{c}\text { Soil } \\
\mathrm{pH}\end{array}$ & $\begin{array}{c}\text { Total N } \\
(\%)\end{array}$ \\
\hline Organic & $2.4 \mathrm{a}$ & $6.9 \mathrm{a}$ & $0.41 \mathrm{a}$ \\
Conventional & $1.8 \mathrm{~b}$ & $5.8 \mathrm{~b}$ & $0.28 \mathrm{~b}$ \\
\hline
\end{tabular}

Note: The numbers followed by different letters in the same column show significant different results according to the T-test $(\alpha=0.05)$

Afandi et al. (2015) have stated that the more organic material is added to the soil, the increase in organic $\mathrm{C}$ content resulting from the decomposition process is higher. The organic $\mathrm{C}$ content in organic paddy fields was the highest because the input was fertilized with cow manure and had a greatly diverse vegetation, especially from grass plants that were decomposed into SOM. The plant materials left in the field, will undergo a decomposition process that is a source of nutrients for plants (Liu et al., 2013).

Based on the ratings provided by the Soil Research Institute (2009), the results of soil pH analysis presented in Table 2 revealed that soil $\mathrm{pH}$ in some locations varied, from acidic, slightly acidic to neutral. The sample point in organic paddy soils had a soil $\mathrm{pH}$ ranging from 7.3 to 6.9 (neutral). Soil $\mathrm{pH}$ in conventional paddy fields reached 5.0-5.1 (acid), particularly in conventional 1 and 5, while at the conventional paddy fields $2,3,4$ and 6 , the $\mathrm{pH}$ ranged from 6.1 to 6.4 , classified as slightly acidic. The highest soil $\mathrm{pH}$ level (7.3) occurred at the sample point of organic paddy field 5, while the lowest level, which was 5.0 , occurred at the sample point of conventional paddy field 5 . The results of the statistical analysis (T-test) are displayed in Table 3. The results of the analysis indicated a significant average difference between the degree of soil $\mathrm{pH}$ in organic paddy fields and the $\mathrm{pH}$ level of soil in conventional paddy fields. The $\mathrm{pH}$ level of soil in organic paddy fields had an average score of 6.9 , while the average $\mathrm{pH}$ level of conventional paddy fields was 5.8 with a significant difference at $p<0.01$. Soil $\mathrm{pH}$ is a major factor affecting the availability of soil nutrients and chemicals in the soil. Land use and topographic are the underlying factors (Yan et al., 2019). Acid soils limit the efficient use of $\mathrm{N}$, $\mathrm{P}, \mathrm{K}, \mathrm{Ca}, \mathrm{Mg}$ and $\mathrm{Mo}$, as well as $\mathrm{Al}$ and $\mathrm{Mn}$ toxicity, leading to low availability of nutrients, resulting in low crop yields. Organic matter releases negative charges to bind $\mathrm{H}^{+}$in acidic soils, or releases $\mathrm{H}^{+}$in subgrade. Increasing the amount of organic matter at the soil surface can increase and stabilize soil $\mathrm{pH}$ in acid soils (McCauley et al., 2017).

Based on the assessment from the Soil Research Institute (2009), the results of the analysis of $\mathrm{N}$ content of all paddy soils shown in Table 2 indicated that the total $\mathrm{N}$ content of soils was moderate, ranging between $0.25 \%$ and $0.45 \%$. In general, organic paddy soils had a 
higher total $\mathrm{N}$ content, compared to conventional paddy soils. The sample point in organic paddy soils had a total soil $\mathrm{N}$ ranging from $0.33 \%$ to $0.45 \%$ (moderate). Conventional paddy soils had a total $\mathrm{N}$ of soil ranging between $0.25 \%$ and $0.31 \%$ (moderate). The highest total $\mathrm{N}$ content of soil was found at organic sample point 1 , which was $0.45 \%$, while the lowest total $\mathrm{N}$ content of soil was found in conventional sample point 6 , which was $0.25 \%$. The outcomes of the statistical analysis (T-test) are presented in Table 3. The results of the analysis demonstrated that there was a significant average difference between the total $\mathrm{N}$ content of soils in organic paddy fields and the total $\mathrm{N}$ content of soils in conventional paddy fields. The total $\mathrm{N}$ content of soils in organic paddy fields had an average of $0.41 \%$, while the average $\mathrm{N}$ content in the conventional paddy fields was $0.28 \%$ with a significant difference value at $\mathrm{p}<0.01$. Low input production systems, $\mathrm{N}$ release from SOM turnover, is the major part of the crop's N supply (Nendel et al., 2019). Wang et al. (2015) mentioned that by reducing or inhibiting the process of nitrification in paddy fields, plants can take more available $\mathrm{NH}_{4}{ }^{+}$, thereby increasing the efficiency of $\mathrm{N}$ absorption and reducing the environmental impact caused by $\mathrm{N}$ losses.

\section{The biological activities in organic and conventional paddy fields}

Based on the calculation of the total soil bacterial colonies presented in Table 4, the highest total soil bacterial colonies were found at the organic point sample $1,30.9 \times 10^{8} \mathrm{CFU} \mathrm{g}^{-1}$ with organic $\mathrm{C}$ content of $2.6 \%$, while the lowest total bacterial colonies were found in conventional sample point $2,4.1 \times 10^{8} \mathrm{CFU} \mathrm{g}{ }^{-1}$ with organic $\mathrm{C}$ content of $1.5 \%$. The results of the statistical analysis (T-test) of total bacterial colonies are shown in Table 5. The results revealed a very significant average difference between the total bacterial colonies in organic paddy fields and the total bacterial colonies in conventional paddy fields. Based on the average value, it is known that the average of organic paddy fields was greater,

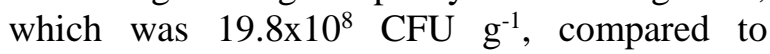
conventional paddy fields, which was equal to $5.3 \times 10^{8} \mathrm{CFU} \mathrm{g}^{-1}$ with a significant value (difference at $\mathrm{p}<0.01$ ).

Table 4. The content of organic $\mathrm{C}$, total bacterial colonies, soil respiration and microbial biomass $\mathrm{C}$ at each sample points

\begin{tabular}{lccc}
\hline \multicolumn{1}{c}{ Sample point } & $\begin{array}{c}\text { Total bacterial } \\
\text { colonies }(\mathrm{CFU} \mathrm{gr}\end{array}$ & $\begin{array}{c}\text { Soil respiration } \\
\left(\mathrm{mg} \mathrm{CO}_{2} \text { week }^{-1}\right)\end{array}$ & $\begin{array}{c}\text { Microbial biomass C } \\
\left(\mu \mathrm{g} \mathrm{g}^{-1}\right)\end{array}$ \\
\hline Organic 1 & $30.9 \times 10^{8}$ & $33.05( \pm 1.63) \mathrm{I}$ & $1.30 \pm 0.32$ \\
Organic 2 & $17.9 \times 10^{8}$ & $28.80( \pm 0.08) \mathrm{M}$ & $0.86 \pm 0.21$ \\
Organic 3 & $13.3 \times 10^{8}$ & $26.33( \pm 1.19) \mathrm{M}$ & $0.74 \pm 0.18$ \\
Organic 4 & $20.0 \times 10^{8}$ & $30.03( \pm 1.65) \mathrm{M}$ & $0.88 \pm 0.22$ \\
Organic 5 & $23.0 \times 10^{8}$ & $30.99( \pm 0.85) \mathrm{M}$ & $1.14 \pm 0.28$ \\
Organic 6 & $13.5 \times 10^{8}$ & $26.88( \pm 1.19) \mathrm{M}$ & $0.80 \pm 0.20$ \\
Conventional 1 & $8.4 \times 10^{8}$ & $21.67( \pm 1.07) \mathrm{M}$ & $0.39 \pm 0.10$ \\
Conventional 2 & $4.1 \times 10^{8}$ & $19.06( \pm 0.92) \mathrm{M}$ & $0.14 \pm 0.04$ \\
Conventional 3 & $5.3 \times 10^{8}$ & $20.43( \pm 0.69) \mathrm{M}$ & $0.39 \pm 0.10$ \\
Conventional 4 & $12.5 \times 10^{8}$ & $25.37( \pm 1.54) \mathrm{M}$ & $0.68 \pm 0.17$ \\
Conventional 5 & $8.4 \times 10^{8}$ & $22.22( \pm 0.17) \mathrm{M}$ & $0.46 \pm 0.11$ \\
Conventional 6 & $10.9 \times 10^{8}$ & $22.77( \pm 0.74) \mathrm{M}$ & $0.62 \pm 0.15$ \\
\hline
\end{tabular}

Note: $\mathrm{M}=$ Moderate; $\mathrm{L}=$ Low; $\mathrm{I}=$ Ideal

Table 5. The results of analysis of T-test organic $\mathrm{C}$ content, total bacterial colonies, soil respiration and microbial biomass $\mathrm{C}$

\begin{tabular}{lccc}
\hline $\begin{array}{c}\text { Paddy field } \\
\text { management system }\end{array}$ & $\begin{array}{c}\text { Total bacterial colonies } \\
(\mathrm{CFU} \mathrm{g})\end{array}$ & $\begin{array}{c}\text { Soil respiration } \\
\left(\mathrm{mg} \mathrm{CO}_{2} \text { week }^{-1}\right)\end{array}$ & $\begin{array}{c}\mathrm{C} \text { microbial biomass } \\
\left(\mu \mathrm{g} \mathrm{g}^{-1}\right)\end{array}$ \\
\hline Organic & $19.8 \times 10^{8} \mathrm{a}$ & $29.34 \mathrm{a}$ & $0.95 \mathrm{a}$ \\
Conventional & $8.3 \times 10^{8} \mathrm{~b}$ & $21.92 \mathrm{~b}$ & $0.44 \mathrm{~b}$ \\
\hline
\end{tabular}

Note: The numbers followed by different letters in the same column show significant different results according to the T-test $(\alpha=0.05)$ 
Zhichen et al. (2015) have stated that land without tillage has a low level of disturbance so that it protects microbial life and is suitable for its breeding. The amount of $\mathrm{CO}_{2}$ produced by soil respiration (microbes) based on the results of soil respiration analysis presented in Table 4 confirms that the highest soil respiration was at organic point sample 1, which was $33.05 \mathrm{mg} \mathrm{CO}_{2}$ week $^{-1}$ with the organic $\mathrm{C}$ content of $2.6 \%$, while the lowest soil respiration was at conventional sample point 2, which was $19.06 \mathrm{mg} \mathrm{CO}_{2}$ week $^{-1}$ with the organic $\mathrm{C}$ content of $1.5 \%$. The results of the statistical analysis (T-test) of soil respiration are displayed in Table 5. The results indicate that there was a vastly significant average difference between soil respiration in organic paddy and that in conventional paddy fields. Based on the average value of soil respiration it is known that the average in organic paddy fields is greater by $29.34 \mathrm{mg} \mathrm{CO}_{2}$ week $^{-1}$ compared to conventional paddy fields which is equal to $21.92 \mathrm{mg} \mathrm{CO}$ week $^{-1}$ with a significant (difference at $\mathrm{p}<0.01$ ).

Soil respiration is the largest $\mathrm{C}$ flux from terrestrial ecosystems to the atmosphere (Yan et al., 2019). The higher the total number of microorganisms and the increasing amount of organic material in the soil, the higher the value of microorganism respiration will be. Increased respiration rate also increases the rate of decomposition of organic matter that accumulates in the soil, metabolic processes that produce waste products in the form of $\mathrm{CO}_{2}$ and $\mathrm{H}_{2} \mathrm{O}$ and the release of energy (Jauhiainen et al., 2012). According to Hedo de Santiago et al. (2016), the low respiration value due to poor restoration of vegetation that causes the recovery of little organic matter in the soil.

The analysis of soil microbial biomass $\mathrm{C}$ summarized in Table 4 shows that the highest soil microbial biomass $\mathrm{C}$ was found at sample point of organic sample point 1 , which was $1.30 \mu \mathrm{g} \mathrm{g}^{-1}$ with the organic $\mathrm{C}$ content of $2.6 \%$, while the lowest microbial biomass $\mathrm{C}$ was found at sample point conventional 2 , which was $0.14 \mu \mathrm{g} \mathrm{g}^{-1}$ with the organic $\mathrm{C}$ content of $1.5 \%$. The results of statistical analysis (T-test) of microbial biomass are shown in Table 5. The results show a highly significant average difference between microbial biomass $\mathrm{C}$ in the organic paddy fields and in the conventional paddy fields. Based on the average $\mathrm{C}$ value in soil microbial biomass, it is apparent that the average value in organic paddy fields was greater, which was $0.95 \mu \mathrm{g} \mathrm{g}^{-1}$, compared to the average value in conventional paddy fields, which was $0.44 \mu \mathrm{g} \mathrm{g}^{-1}$, with a significant difference at $\mathrm{p}<0.01$. The high value of soil microbial biomass $\mathrm{C}$ on a land can be caused by several conditions supporting the availability of abundant litter as a food source of microorganisms, land cover density and organic C content (Chen et al., 2010; Fang et al., 2014; da Silva et al., 2014). Microbes and organic $\mathrm{C}$ are generally more sensitive to land-use changes than physical properties (Sharma et al., 2012). Microbial biomass decreases more rapidly after land-use changes (Guillaume et al., 2016). Soil microbial biomass accounts for $1-3 \%$ of the total organic $\mathrm{C}$ in soil and provides nutrients through the mineralization process (Santos et al., 2012).

The results of correlation analysis (Table 6) show that there was a strong positive correlation among organic $\mathrm{C}$ and soil $\mathrm{pH}(\mathrm{r}=0.729)$, total $\mathrm{N}$ $(\mathrm{r}=0.769)$, total bacterial colonies $(\mathrm{r}=0.919)$, soil respiration ( $\mathrm{r}=0.974)$ and microbial biomass $\mathrm{C}$ $(r=0.942)$. Supriyadi (2008) has reported that organic matter has an important role in determining soil quality for the sustainability of agricultural production through its effect on the physical, chemical and biological properties of the soil.

Table 6. The results of correlation analysis between the content of organic $\mathrm{C}, \mathrm{pH}$, total $\mathrm{N}$ and biological activity (total colony of bacteria, soil respiration and microbial biomass $\mathrm{C}$ )

\begin{tabular}{lccccc}
\hline \multicolumn{1}{c}{ Parameters } & Soil pH & $\begin{array}{c}\text { Total } \\
\text { nitrogen }\end{array}$ & $\begin{array}{c}\text { Total bacterial } \\
\text { colonies }\end{array}$ & $\begin{array}{c}\text { Soil } \\
\text { respiration }\end{array}$ & $\begin{array}{c}\text { Microbial } \\
\text { biomass C }\end{array}$ \\
\hline Organic C & $0.729^{* *}$ & $0.769^{* *}$ & $0.919^{* *}$ & $0.974^{* *}$ & $0.942^{* *}$ \\
Soil pH & & $0.646^{*}$ & $0.596^{*}$ & $0.693^{*}$ & $0.680^{*}$ \\
Total nitrogen & & & $0.692^{*}$ & $0.741^{* *}$ & $0.709^{* *}$ \\
Total bacterial colonies & & & & $0.969^{* *}$ & $0.969^{* *}$ \\
Soil respiration & & & & & $0.975^{* *}$ \\
\hline
\end{tabular}

Note: $* *=$ Correlation is significant at the 0.01 level $(2$-tailed); $*=$ Correlation is significant at the 0.05 level (2-tailed) 


\section{CONCLUSIONS}

The $\mathrm{C}$ in organic paddy fields $(2.4 \%)$ was higher than the content in conventional paddy fields $(1.8 \%)$. The $\mathrm{C}$ content in organic paddy fields increased by $0.6 \%$, compared to the $\mathrm{C}$ content in conventional paddy fields. Organic paddy fields had higher values of various aspects, including the total bacterial colonies (19.8 CFU $\mathrm{g}^{-1}$ ), soil respiration $\left(29.34 \mathrm{mg} \mathrm{CO}_{2}\right.$ week $\left.^{-1}\right)$ and microbial biomass $\mathrm{C} \quad\left(0.95 \mu \mathrm{g} \quad \mathrm{g}^{-1}\right)$, than conventional paddy fields, with $\left(8.3 \mathrm{CFU} \mathrm{g}^{-1}\right)$, (21.92 $\mathrm{mg} \mathrm{CO}_{2}$ week $\left.^{-1}\right)$ and $\left(0.44 \mu \mathrm{g} \mathrm{g}^{-1}\right)$, because the application of organic farming systems could improve the characteristics of soil biological characteristics. Increased $\mathrm{C}$ content in organic paddy fields by $0.6 \%$ was caused by high biological activity, compared to conventional paddy fields. The differences of the total bacterial colonies, soil respiration, and microbial biomass $\mathrm{C}$ between organic paddy fields and conventional

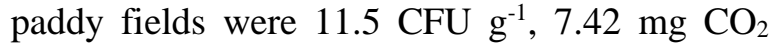
week $^{-1}$ and $0.51 \mu \mathrm{g} \mathrm{g}^{-1}$, respectively.

\section{ACKNOWLEDGEMENT}

This study was supported by the Ministry of Research, Technology and Higher Education of the Republic of Indonesia and Universitas Sebelas Maret, Surakarta.

\section{REFERENCES}

Afandi, F. N., Siswanto, B., \& Nuraini, Y. (2015). Pengaruh Pemberian Berbagai Jenis Bahan Organik terhadap Sifat Kimia Tanah pada Pertumbuhan dan Produksi Tanaman Ubi Jalar di Entisol Ngrangkah Pawon, Kediri. Jurnal Tanah dan Sumberdaya Lahan, 2(2), 237-244. Retrieved from https://jtsl.ub.ac.id/index.php/ jtsl/article/view/134

Anas, I. (1989). Biologi Tanah dalam Praktik. Departemen Pendidikan dan Kebudayaan Direktorat Jendaral Pendidikan Tinggi Pusat antar Universitas Bioteknologi Institut Pertanian Bogor. Bogor. 173 hlm.

Arunrat, N., Pumijumnong, N., \& Hatano, R. (2017). Practices Sustaining Soil Organic Matter and Rice Yield in a Tropical Monsoon Region. Soil Science and Plant Nutrition, 63(3), 274-287. https://doi.org/10.1080/0038 0768.2017 .1323546
Bhattacharyya, R., Prakash, V., Kundu, S., Srivastva, A. K., Gupta, H. S., \& Mitra, S. (2010). Long Term Effects of Fertilization on Carbon and Nitrogen Sequestration and Aggregate Associated Carbon and Nitrogen in the Indian sub-Himalayas. Nutrient Cycling in Agroecosystems, 86(1), 1-16. https://doi.org/ 10.1007/s10705-009-9270-y

Chen, D. D., Zhang, S. H., Dong, S. K., Wang, X. T., \& Du, G. Z. (2010). Effect of Land-Use on Soil Nutrients and Microbial Biomass of an Alpine Region on the Northeastern Tibetan Plateau, China. Land Degradation \& Development, 21(5), 446-452. https://doi.org/ 10.1002/ldr.990

da Silva, A. P., Babujia, L. C., Franchini, J. C., Ralisch, R., Hungria, M., \& Guimarães, M. de F. (2014). Soil Structure and its Influence on Microbial Biomass in Different Soil and Crop Management Systems. Soil and Tillage Research, 142, 42-53. https://doi.org/10.1016/ j.still.2014.04.006

Fageria, N. K., dos Santos, A. B., \& Coelho, A. M. (2011). Growth, Yield and Yield Components of Lowland Rice as Influenced by Ammonium Sulfate and Urea Fertilization. Journal of Plant Nutrition, 34(3), 371-386. https://doi.org/10.1080/01904167.2011.53687 9

Fang, X., Wang, Q., Zhou, W., Zhao, W., Wei, Y., Niu, L., \& Dai, L. (2014). Land Use Effects on Soil Organic Carbon, Microbial Biomass and Microbial Activity in Changbai Mountains of Northeast China. Chinese Geographical Science, 24, 297-306. https://doi.org/10.1007/ s11769-014-0670-9

Ghimire, R., Lamichhane, S., Acharya, B. S., Bista, P., \& Sainju, U. M. (2017). Tillage, Crop Residue, and Nutrient Management Effects on Soil Organic Carbon in Rice-Based Cropping Systems: a review. Journal of Integrative Agriculture, 16(1), 1-15. https://doi.org/10.10 16/S2095-3119(16)61337-0

Guillaume, T., Maranguit, D., Murtilaksono, K., \& Kuzyakov, Y. (2016). Sensitivity and Resistance of Soil Fertility Indicators to LandUse Changes: New Concept and Examples from Conversion of Indonesian Rainforest to 
Plantations. Ecological Indicators, 67, 49-57. https://doi.org/10.1016/j.ecolind.2016.02.039

Hedo de Santiago, J., Lucas-Borja, M. E., WicBaena, C., Andrés-Abellán, M., \& de las Heras, J. (2016). Effects of Thinning and Induced Drought on Microbiological Soil Properties and Plant Species Diversity at Dry and Semiarid Locations: Thinning and Induced Drought in Mediterranean Soils. Land Degradation \& Development, 27(4), 11511162. https://doi.org/10.1002/ldr.2361

Jauhiainen, J., Hooijer, A., \& Page, S. E. (2012). Carbon Dioxide Emissions from an Acacia Plantation on Peatland in Sumatra, Indonesia. Biogeosciences, 9(2), 617-630. https://doi. org/10.5194/bg-9-617-2012

Lal, R. (2004). Soil Carbon Sequestration Impacts on Global Climate Change and Food Security. Science, 304(5677), 1623-1627. https://doi. org/10.1126/science. 1097396

Lal, R. (2011). Sequestering carbon in soils of agro-ecosystems. Food Policy, 36(1), S33S39. https://doi.org/10.1016/j.foodpol.2010.1 2.001

Liu, C. H., Liu, Y., Fan, C., \& Kuang, S. Z. (2013). The Effects of Composted Pineapple Residue Return on Soil Properties and the Growth and Yield of Pineapple. Journal of Soil Science and Plant Nutrition, 13(2), 433-444. https://doi.org/10.4067/S0718-951620130050 00034

Liu, X., Wang, H., Zhou, J., Hu, F., Zhu, D., Chen, Z., \& Liu, Y. (2016). Effect of N Fertilization Pattern on Rice Yield, N Use Efficiency and Fertilizer-N Fate in the Yangtze River Basin, China. PLoS ONE, 11(11), e0166002. https:// doi.org/10.1371/journal.pone.0166002

Lu, F., Wang, X., Han, B., Ouyang, Z., Duan, X., Zheng, H., \& Miao, H. (2009). Soil Carbon Sequestrations by Nitrogen Fertilizer Application, Straw Return and No-Tillage in China's Cropland. Global Change Biology, 15(2), 281-305. https://doi.org/10.1111/j.1365 $-2486.2008 .01743 . \mathrm{x}$

McCauley, A., Jones, C., \& Olson-Rutz, K. (2017). Soil pH and Organic Matter, Nutrient Management Module No. 8. Bozeman: Montana State University.
Nachimuthu, V. V., Muthurajan, R., Duraialaguraja, S., Sivakami, R., Pandian, B. A., Ponniah, G., Gunasekaran, K., Swaminathan, M., K K, S., \& Sabariappan, R. (2015). Analysis of Population Structure and Genetic Diversity in Rice Germplasm Using SSR Markers: an Initiative Towards Association Mapping of Agronomic Traits in Oryza sativa. Rice, 8(1), 30. https://doi.org/ 10.1186/s12284-015-0062-5

Nendel, C., Melzer, D., \& Thorburn, P. J. (2019). The Nitrogen Nutrition Potential of Arable Soils. Scientific Reports, 9(1), 5851. https:// doi.org/10.1038/s41598-019-42274-y

Nguyen, M. T. (2006). The effect of temperature on the growth of the bacteria Escherichia coli DH5a. Saint Martin's University Biology Journal, 1, 87-94. Retrieved from https://pdfs. semanticscholar.org/031b/a106eb18968c60ed fb24bfeb5c1941328fec.pdf

Pospíšilová, L., Formanek, P., Kucerik, J., Liptaj, T., Losak, T., \& Martensson, A. (2011). Land Use Effects on Carbon Quality and Soil Biological Properties in Eutric Cambisol. Acta Agriculturae Scandinavica, Section B - Soil \& Plant Science, 61(7), 661-669. https://doi.org/ 10.1080/09064710.2010.539576

Prasetyo, B. H. (2008). Karakteristik Tanah Sawah dari Endapan Aluvial dan Pengelolaannya. Jurnal Sumberdaya Lahan, 2(1), 1-14. Retrieved from https://media.neliti. com/media/publications/132791-ID-none.pdf

Santos, V. B., Araújo, A. S. F., Leite, L. F. C., Nunes, L. A. P. L., \& Melo, W. J. (2012). Soil Microbial Biomass and Organic Matter Fractions During Transition from Conventional to Organic Farming Systems. Geoderma, 170, 227-231. https://doi.org/10. 1016/j.geoderma.2011.11.007

Sharma, P., Jha, A. B., Dubey, R. S., \& Pessarakli, M. (2012). Reactive Oxygen Species, Oxidative Damage, and Antioxidative Defense Mechanism in Plants under Stressful Conditions. Journal of Botany, 2012, 1-26. https://doi.org/10.1155/2012/217037

Soil Research Institute. (2009). Chemical Analysis of Soil, Plants, Water and Fertilizers. Bogor: Institute for Soil Research. 
Supriyadi, S. (2008). Kandungan Bahan Organik sebagai Dasar Pengelolaan Tanah di Lahan Kering Madura. EMBRYO, 5(2), 176-183. Retrieved from http://pertanian.trunojoyo.ac. id/wp-content/uploads/2012/03/6-KANDU NGAN-SLAMET.pdf

Viscarra Rossel, R. A., Lee, J., Behrens, T., Luo, Z., Baldock, J., \& Richards, A. (2019). Continental-Scale Soil Carbon Composition and Vulnerability Modulated by Regional Environmental Controls. Nature Geoscience, 12(7), 547-552. https://doi.org/10.1038/s415 61-019-0373-Z

Wang, W., Lai, D. Y. F., Wang, C., Pan, T., \& Zeng, C. (2015). Effects of Rice Straw Incorporation on Active Soil Organic Carbon Pools in a Subtropical Paddy Field. Soil and Tillage Research, 152, 8-16. https://doi.org/ 10.1016/j.still.2015.03.011

Yan, T., Song, H., Wang, Z., Teramoto, M., Wang, J., Liang, N., Ma, C., Sun, Z., Xi, Y., Li, L., \& Peng, S. (2019). Temperature Sensitivity of Soil Respiration Across Multiple Time Scales in a Temperate Plantation Forest. Science of the Total Environment, 688, 479-
485. https://doi.org/10.1016/j.scitotenv.2019.0 6.318

Zhang, X., Sun, N., Wu, L., Xu, M., Bingham, I. J., \& Li, Z. (2016). Effects of Enhancing Soil Organic Carbon Sequestration in the Topsoil by Fertilization on Crop Productivity and Stability: Evidence from Long-Term Experiments with Wheat-Maize Cropping Systems in China. Science of The Total Environment, 562, 247-259. https://doi.org/ 10.1016/j.scitotenv.2016.03.193

Zhao, Y.-N., He, X.-H., Huang, X.-C., Zhang, Y.Q., \& Shi, X.-J. (2016). Increasing Soil Organic Matter Enhances Inherent Soil Productivity while Offsetting Fertilization Effect under a Rice Cropping System. Sustainability, 8(9), 879. https://doi.org/10.33 90/su8090879

Zhichen, Y., Hong, L., \& Jinshun, B. (2015). Effects on Soil Organic Carbon and Microbial Biomass Carbon of Different Tillage. Proceedings of the 2015 AASRI International Conference on Circuits and Systems. 2015 AASRI International Conference on Circuits and Systems (CAS 2015), Paris, France. https://doi.org/10.2991/cas-15.2015.6 